\section{さく孔深さの影響を考慮した長尺さく孔データと 岩盤特性の関係に関する検討*}

山下 雅之票井勝 則 $^{2}$ 大久保誠介 ${ }^{3}$

\title{
Correlation between Drilling Data and Rock Mass Properties Focused on the Effect of Hole Length
}

by Masayuki YAMASHITA ${ }^{\mathrm{a}}$, Katsunori FUKUI ${ }^{\mathrm{b}}$ and Seisuke OKUBO ${ }^{\mathrm{b}}$

a. Technical Research Institute, Nishimatsu Construction Co., Ltd., 2570-4, Shimoturuma, Yamato, Kanagawa, 424-8520, Japan

(Corresponding author:E-mail masayuki_yamashita@nishimatsu.co.jp)

b. Department of Geosystem Engineering, The University of Tokyo

On tunnel excavation, a prediction of geological conditions ahead of face is of the utmost importance to keep rapid driving and safety works. Fukui et al. in 2004 investigated the drilling performance at Suzuka tunnel with special care to the effect of hole length up to $50 \mathrm{~m}$, and proposed $V^{*}$ (normalized penetration rate) to estimate rock mass properties ahead of face. In this study, the method proposed by Fukui et al. was fully discussed and slightly modified. Thereafter, the method was applied to estimate rock mass properties at Suzuka tunnel and systematic insitu measurements of $V^{*}$ were carried out through the tunnel. It was found that the reciprocal of $V^{*}$ is a good indicator for rock mass properties and suits the in-situ usage. The reciprocal of $V^{*}$ has strong correlation with rock mass strength estimated by TBM cutting force and very useful to estimate and predict the rock mass properties ahead of face. For example, a fracture zone can be predicted by an abrupt change of the magnitude.

KEY WORDS : Rock Drill, Long-Hole Drilling, Tunnel, Forefield Exploration, Rock Mass Property

\section{1.は じめに}

TBM ( 全断面トンネル掘進機) 工法は他工法に比べて高速掘進 が期待される反面，予期せぬ地山脆弱層や大量湧水に遭遇した場 合に長期の掘削停止を強いられる場合も少なくない。そのため, 高速掘進を確保するためには切羽およびその前方の地質性状を迅 速かつ精度よく把握することが重要となる。

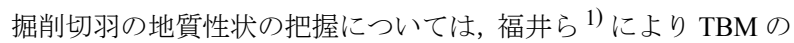
掘削抵抗から岩盤強度を推定する手法が提案されており,これまで に TBM トンネルへの適用事例が多数報告されている ${ }^{2-4)}$ 。切羽前 方地質の把握については, その簡便性から TBM に搭載されたさく 岩機による長尺さく孔探査 (ノンコア先進ボーリング) が用いられ ることが多く ${ }^{5-9)}$, 例えば山本ら ${ }^{9)}$ はさく孔データと TBM 掘削デー 夕の関係に基づき岩盤特性の把握に関する検討を行っている。

長尺さく孔では, 岩盤特性の評価をさく孔速度やさく孔速度等 から求めた掘削体積比エネルギーを用いて行う場合が多いが，さ く孔深さの増加に伴うロッド中での弾性波の減衰や, 孔壁とロッ ドの摩擦等によるエネルギー損失の増大がさく孔速度に影響を及 ぼすことが以前より指摘されていた 10)。これに対して福井ら 11) は, 同一トンネルで得られた 68 回の長尺さく孔データを用いてさ く孔速度が受けるさく孔深さの影響について検討し，その影響を

* 2004 年 5 月 31 日受付 8 月 4 日受理

1. 普通会員 西松建設 (株) 技術研究所

2. 普通会員 工博 東京大学助教授 工学系研究科 地球システム工学専攻

3. 普通会員 工博 東京大学教授 工学系研究科 地球システム工学専攻

[著者連絡先] FAX 046-275-6796 (西松建設 (株) ・ 技術研究所)

E-mail : masayuki_yamashita@nishimatsu.co.jp

キーワード：さく岩機，長尺さく孔，トンネル，前方探査，岩盤特性
除去する手段として各深度の平均さく孔速度で探査データを正規 化する手法を提案した。

本研究では, 福井ら ${ }^{11)}$ の提案した手法により得られたさく孔深 さの影響を考慮したさく孔データと TBM 掘削データおよび地質 観察等による岩盤性状を比較し, さく孔データと岩盤特性の関係 に関する検討を行った。

\section{2. トンネルの概要およびさく孔探査・TBM 掘削データ}

\section{$2 \cdot 1$ トンネルの概要}

対象としたトンネルは，第二名神高速道路鈴鹿トンネル上り線 工事である。図 1 に示すように, 本トンネルは鈴鹿山脈の南端部 を東西に貫く延長約 $3.9 \mathrm{~km}$ の長大トンネルであり, 掘削は三重県 の東側坑口付近に設けられた作業横坑から $2 \%$ の上り勾配で滋賀 県の西側坑口へ( 図中右側から左側一) と進められる。また, 卜 ンネル断面は片側 3 車線を確保するために約 $190 \mathrm{~m}^{2}$ の大断面を形 成しており, 掘削工法は直径 $5.0 \mathrm{~m}$ の TBM による約 $20 \mathrm{~m}^{2}$ の導坑 先進工法が採用されている。

トンネル周辺には中生代白亜紀の花崗岩 ( 鈴鹿花崗岩) および 第三紀中新世の砂岩, 泥岩および砶岩からなる鮎川層群が広く分 布している。鈴鹿花崗岩は主に三重県側に分布し, 鮎川層群は滋 賀県側に広く分布しており, 両者は黒滝断層によって境されてい る。また, 黒滝断層付近の花崗岩部には中生代ジュラ紀のホルン フェルス (田村川層) が部分的に分布している。これら地質の物 性値については, ボーリング試料の一軸圧縮強度として鈴鹿花崗 岩で $6.1 \sim 91.5 \mathrm{MPa}$, 鮎川層群の砂岩・泥岩層で $1.8 \sim 44.3 \mathrm{MPa}$ と いう值が事前調査で報告されている。

$2 \cdot 2$ さく孔データ 


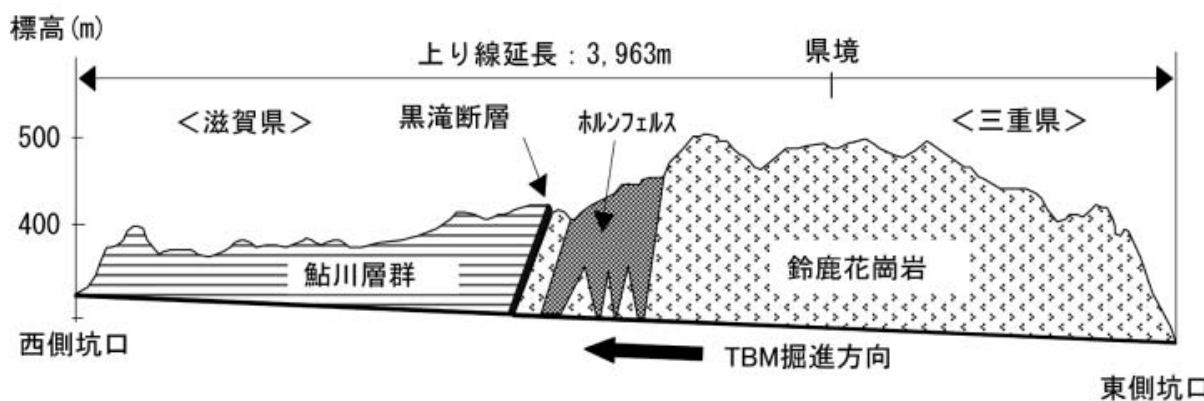

図 1 鈴鹿トンネルの地質概要

東側坑口

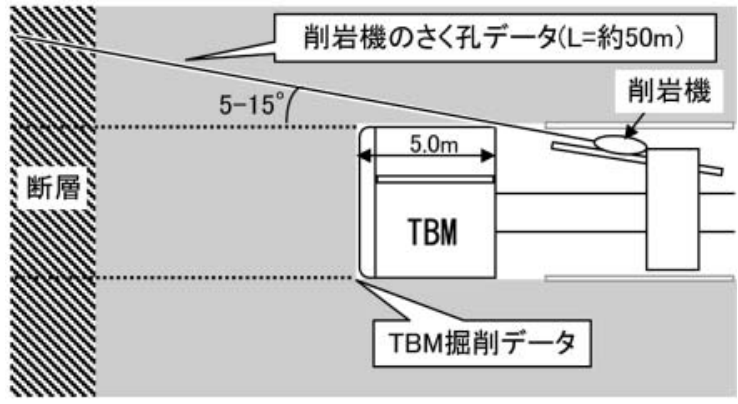

図 2 さく孔探査の概念図

さく孔探査は TBM 先進導坑掘削時の切羽前方探査として TBM トンネル全線で実施された。探査には TBM に装備されている油 圧さく岩機を使用し, 図 2 に示すように切羽後方約 $5 \mathrm{~m}$ ( ルーフサ ポート後端付近）の天端部より約 $50 \mathrm{~m}$ のさく孔深さでさく孔検層 を行った。この際，前回の探査区間と約 $5 \mathrm{~m}$ 重なるように連続的 に実施した。

計測項目はさく孔時のダンピング圧, 回転圧, 打撃圧, スラス 卜圧の各油圧データおよびさく孔深さであり，これらのデータを 各油圧配管中に設置した油圧計または油量計を介してデータレ コーダに 1 秒間隔で記録した。なお，本研究で使用したさく岩機 の種類, ロッド・ビット等のさく孔部材の仕様およびさく孔条件

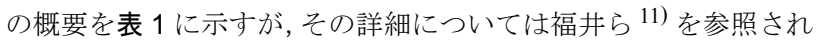
たい。

\section{$2 \cdot 3$ TBM 掘削データ}

本トンネルの先進導坑掘削に使用した TBM の諸元を表 2 に示 す。本研究では TBM 掘削時の推力, トルク, 貫入量 (カッタヘッ ド 1 回転あたりの掘進長 ) 等を約 $2 \mathrm{~cm}$ 間隔で計測し，1 ストロー ク (約 $1.5 \mathrm{~m}$ ) 毎の各項目の平均值を求めた。TBM 掘削データから 岩盤性状を把握する手法として次式に示寸福井ら ${ }^{1,12)}$ による掘削 抵抗からの岩盤強度の算定手法を用いた。

$\sigma_{c}=F /\left(C_{1} \cdot p\right)=T /\left(C_{2} \cdot p^{1.5}\right)$

ここで， $\sigma_{c}$ : 岩盤強度 $(\mathrm{Pa}), F$ : 推力 $(\mathrm{N}), T$ : トルク $(\mathrm{N} \cdot \mathrm{m}), p$ : 貫入量 $(\mathrm{m}), C_{1}, C_{2}: \mathrm{TBM}$ の諸元より求めた定数，である。

本研究では式 (1) 中の推力を用いた算出式を使用し，1 ストロー ク区間毎の平均岩盤強度を求めた。以降の検討で使用する岩盤強 度はこの值を用いることとする。

\section{3. 正規化したさく孔速度と掘削体積比エネルギー}

さく岩機や TBM, 自由断面掘削機等の掘削効率や機械掘削時の 岩盤評価手法として広く利用されている評価パラメータの 1 つに 掘削体積比エネルギーがある ${ }^{13)}$ 。

長孔さく孔の場合には, ロッド中で弾性波が減衰するので, ロッ ドにおけるエネルギー伝達係数 $(-)$ を $T_{R}$ として, ビット先端にお ける掘削体積比エネルギーは次式で表される。
表 1 さく孔の諸元

\begin{tabular}{ll}
\hline さく岩機の種類 & アトラスコプコ社製 COP1440 \\
使用ビット & $\phi 64$ ボタンビット \\
先頭ロッド(チューブロッド) & $\phi 45, \mathrm{~L}=3.0 \mathrm{~m} \times 1$ 本 \\
中継ロッド(スピードロッド) & $\phi 32, \mathrm{~L}=3.0 \mathrm{~m} \times 16$ 本 \\
スラスト & $10.0 \mathrm{kN}$ \\
打撃圧 & $17.5 \mathrm{MPa}$ \\
\hline
\end{tabular}

表 2 TBM $の$ 諸元

\begin{tabular}{lcc}
\hline 型 式 & オープン型TBM \\
掘削径 $(\mathrm{m})$ & 5.00 \\
最大推カ $(\mathrm{kN})$ & 9800 \\
カッタ径 $(\mathrm{mm})$ & $432(17$ inch $)$ \\
カッタヘット゚回転速度 $(\mathrm{rpm})$ & $0.8 \sim 10.0$ \\
カッタ数 $($ 個 $)$ & 35 \\
最大トルク $(\mathrm{kN} \cdot \mathrm{m})$ & 2430 \\
\hline 定数 $\mathrm{C}_{1}(\mathrm{~m})$ & 1 & 16 \\
\hline
\end{tabular}

$E=\left(E i \times b \times T_{R}\right) /(A \times V)$

$E$ : 掘削体積比エネルギー $\left(\mathrm{J} / \mathrm{m}^{3}\right), E i$ : ピストンの 1 打撃直後の ロッド中の弾性波エネルギー $(\mathrm{J}), b$ : 打撃数 (blows/s), $A$ : さく孔断 面積 $\left(\mathrm{m}^{2}\right), V:$ さく孔速度 $(\mathrm{m} / \mathrm{s})$

$E i \times b \times T_{R}$ および $A \times V$ はそれぞれ，ビット先端での単位時間あ たりの入力エネルギー, 単位時間あたりの掘削体積に相当する。 長孔さく孔では, $E i, b, T_{R}$ はさく孔深さによって変化し, 原位 置において $E i, T_{R}$ を求めることは困難であるため, 式 (2)より掘 削体積比エネルギーを求めることは難しい。

$E_{b}\left(=E i \times b \times T_{R}\right)$ はさく孔深さ $L$ の関数で, 掘削体積比エネル ギー $E$ は岩盤特性 $\sigma$ の関数であるので, 次式のようにさく孔速度 は $\sigma$ と $L$ の関数となる ${ }^{11)}$ 。

$V(\sigma, L)=E_{b}(L) /\{A \times E(\sigma)\}$

何回か行ったさく孔試験において, さく孔深さ $L_{0}$ でのさく孔速 度 $V\left(\sigma, L_{0}\right)$ を， $L_{0}$ でのさく孔速度の平均值 $\overline{V\left(L_{0}\right)}$ で割ると式 (3) から次式を得る。

$$
\begin{aligned}
V^{*}\left(\sigma, L_{0}\right) & =V\left(\sigma, L_{0}\right) / \overline{V\left(L_{0}\right)} \\
& =\left[E_{b}\left(L_{0}\right) /\{A E(\sigma)\}\right] /\left[\overline{E_{b}\left(L_{0}\right) /\{A E(\sigma)\}}\right]
\end{aligned}
$$

$E_{b}$ はさく孔深さのみの関数であるので, $E_{b}\left(L_{0}\right)$ は定数である。 よって次式を得る。

$$
V^{*}\left(\sigma, L_{0}\right)=\{1 / E(\sigma)\} /\{\overline{1 / E(\sigma)}\}
$$

式 (5) を書き換えると次式を得る。

$$
E(\sigma)=1 /\left[V^{*}\left(\sigma, L_{0}\right) /\{\overline{1 / E(\sigma)}\}\right]
$$

$\overline{1 / E(\sigma)}$ はさく孔試験の回数が多くなると, 大数の法則よりある 值に近づいていることから定数とみなせるので, 掘削体積比エネ ルギーは $1 / V^{*}$ に比例することとなる。

$E \propto 1 / V^{*}$ 


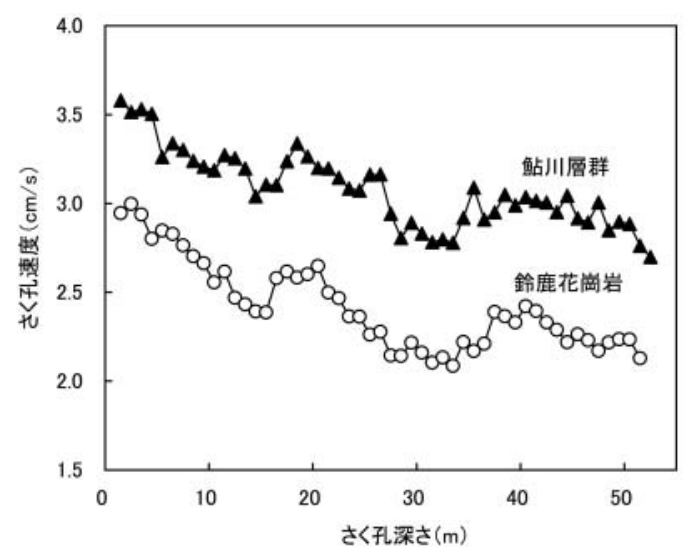

図 3 さく孔速度のさく孔深さによる変化 ${ }^{11)}$

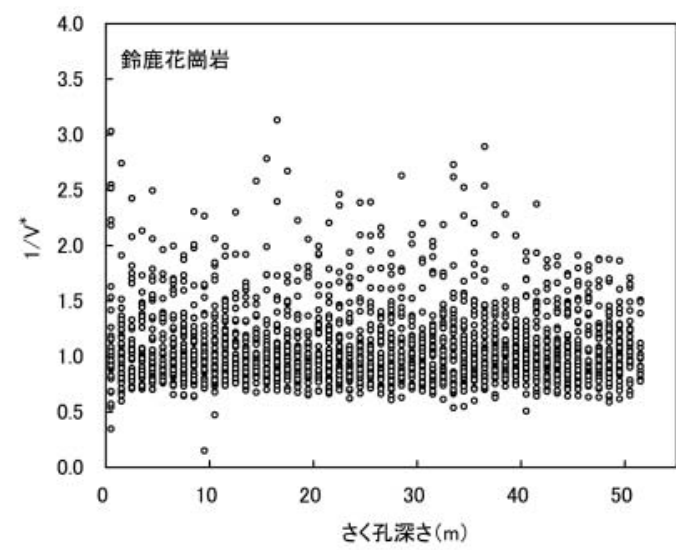

図 4 鈴鹿花崗岩におけるさく孔深さに対する $1 / V^{*}$ の分布

鈴鹿花崗岩 ( さく孔回数 42 回 ) および鮎川層群 (さく孔回数 26 回）を対象にした，さく孔探査での各さく孔深さにおけるさく孔 速度 $\overline{V\left(L_{0}\right)}$ を図 $3^{11)}$ に示すが, さく孔速度と $\overline{V\left(L_{0}\right)}$ から $1 / V^{*}$ を求 めることは容易であり, 本研究では, 掘削体積比エネルギーに比 例する $1 / V^{*}$ と岩盤特性を議論していくことにする。

図 4, 図 5 に鈴鹿花崗岩および鮎川層群におけるさく孔梁さに 対する $1 / V^{*}$ の分布を示す。ここで, 鈴鹿花崗岩の出現区間中に部 分的に認められるホルンフェルスのさく孔データも鈴鹿花崗岩の さく孔データに含めた。さく孔探査によって得られた $1 / V^{*}$ は, そ れぞれ岩種の平均的な岩盤性状を示寸 $1 / V^{*}=1.0$ を中心とした水 平領域に分布しており, さく孔梁さの影響が取り除かれているこ とがわかる。また，1.0を中心とした $1 / V^{*}$ の変動は岩盤性状の変 化を示しており, 鈴鹿花崗岩の $1 / V^{*}$ が鮎川層群のそれよりも変動 幅が大きくなる傾向が認められた。

\section{TBM データから求めた岩盤強度と地質性状の関係}

TBM データから求めた岩盤強度と地質性状の関係については, 例えば花崗岩地山における検討結果から岩盤強度と岩盤等級の相 関が高いことが報告されている12)。本トンネルにおける TBMデー タから得られた岩盤強度および実施支保パターンの掘進距離程 (TD) に伴う変化傾向を図 6 に, 坑壁観察に基づく掘削区間の地質 概要および岩盤強度の傾向を表 3 にそれぞれ示す。なお，図中の 横軸に示した距離程表示は図 1 に示したトンネルの掘進方向 (右 側から左側 ）に合わせ，以降の掘削またはさく孔探査の距離程を 横軸とする図についても同様の表示方法とする。

$4 \cdot 1$ 岩盤強度と坑壁観察に基づく地質性状の関係

主として鈴鹿花崗岩が分布する区間の岩盤強度分布を図 6(a) に

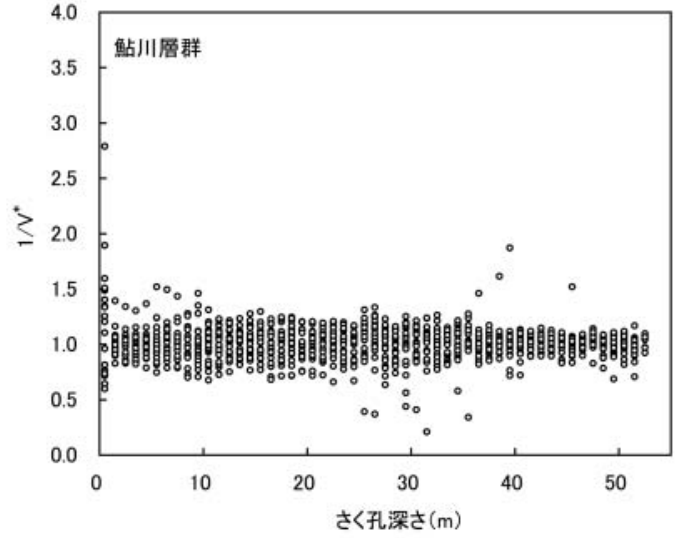

図 5 鮎川層群におけるさく孔深さに対する $1 / V^{*}$ の分布

示す。この中で, TD150〜 1,345m 区間の岩盤強度は $20 \sim 100 \mathrm{MPa}$ を示し, その変動幅は比較的大きい。それに対し, TD $1,345 \mathrm{~m}$ 以降 では岩盤強度の変動幅が小さくなるとともに, 黒滝断層に近づく に従い岩盤強度が概ね $40 \mathrm{MPa}$ から $15 \mathrm{MPa}$ へと低下していく傾向 が認められた。表 3 に示すように, TD150 1,345m 区間の地質性 状は比較的新鮮で硬質な花崗岩中に熱水変質部や小規模断層, 亀 裂密集部などの脆弱層が部分的に繰り返し分布するような性状を 呈している。岩盤強度の変動幅の大きさはこのような岩盤性状を 強く反映したものと考えられる。一方，TD1,345m 以降の区間では 岩芯まで変質を受けたやや脆弱な花崗岩を主体とし, 岩盤の硬軟 の変化が TD $1,345 \mathrm{~m}$ までの区間に比べて比較的小さくなっており, 岩盤強度の傾向と概ね一致している。

鮎川層群の出現区間の岩盤強度分布を図6(b) に示す。この区間 の岩盤強度は前述の変質花崗岩区間と同様に変動幅が小さく概ね $20 \sim 40 \mathrm{MPa}$ を示すが，10MPa 程度にまで低下寸る区間が一部認 められた。表 3 に示すように, この区間の鮎川層群はやや軟質な シルト質泥岩, 砂岩を主体としており, その中に変質帯や亀裂密 集もしくは粘土が介在するような小規模破砕帯が数条認められ た。岩盤強度の低下区間はこれらの変質帯や小規模破砕帯の出現 区間に概ね一致している。

\section{$4 \cdot 2$ 岩盤強度と支保パターンの関係}

岩盤強度と地質性状との関係を掘削時の実施支保パターンとの 関係から求めた。本トンネルにおける支保パターンの選定は, 日 本道路公団の基準に従って求めた切羽評価点, 岩盤の崩落状況等 を考慮して行った。表 4 に示すように鈴鹿花崗岩および鮎川層群 の岩盤強度は，何れの場合も支保パターンが軽くなるに従い平均 值が大きくなる傾向が認められ, 各岩種において岩盤強度と支保 パターンの良好な相関関係が認められる。両岩種における各支保 パターンと岩盤強度の平均值の関係を見てみると, 同じ岩盤強度 に対して, 鮎川層群の方が概ね 1 ランク軽い支保パターンで評価 される傾向がある。

図 7 に各支保パターンにおける岩盤強度の累積確率分布を鈴鹿 花崗岩と鮎川層群の岩種別に示寸。鈴鹿花崗岩では支保パターン が軽くなるに従い累積確率分布曲線の傾きが小さくなる（強度分 布の範囲が広くなる ) 傾向が認められるが, その傾きの変化は C II パターンと C I パターンの間で顕著である。図6(a) および表 3 に示すように, 鈴鹿花崗岩において C II, D I パターンが適用さ れた区間の多くは変質花崗岩 (およびホルンフェルス) に相当し ている。このような岩相の違いが累積確率分布曲線の傾きの顕著 な変化に表れたものと考えられる。鮎川層群の場合, C I および C II パターンの傾きの変化は鈴鹿花崗岩と同様の傾向を示寸が, D 
（a）鈴鹿花崗岩 / ホルンフェルス

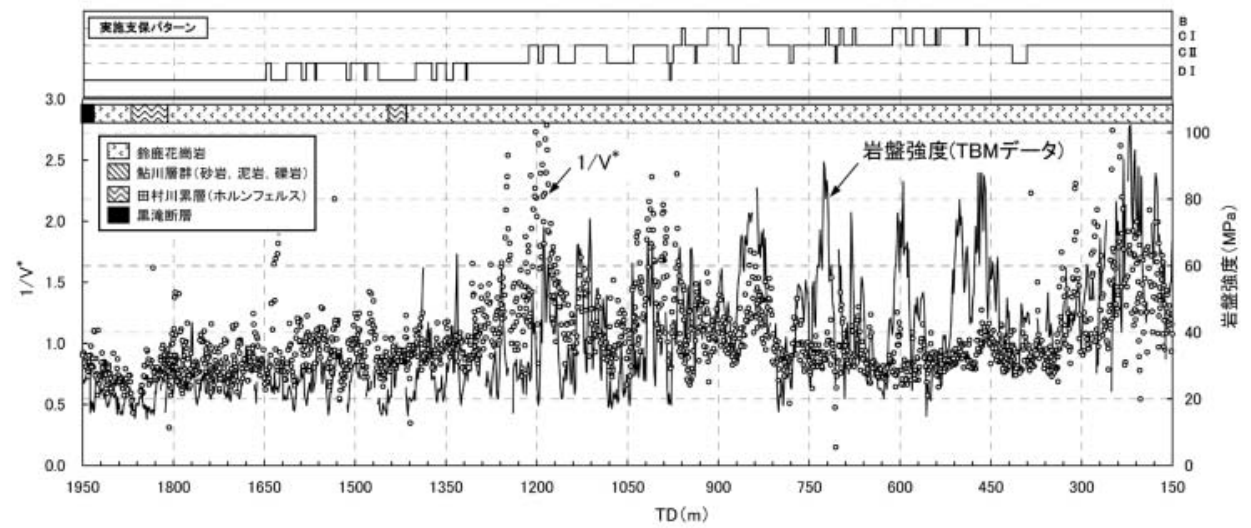

(b) 鮎川層群区間

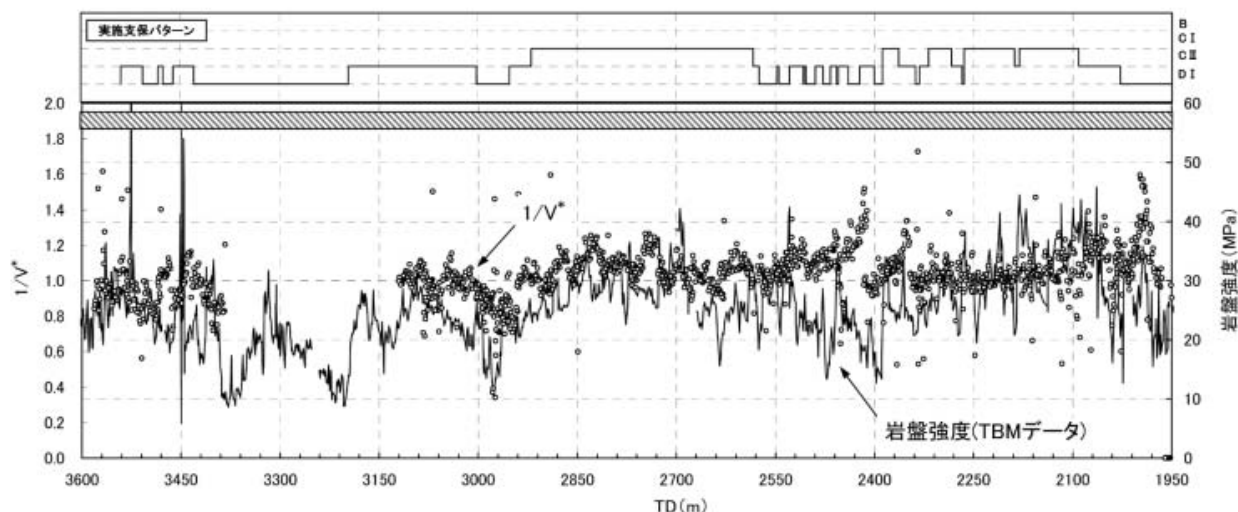

図 6 TBM データから求めた岩盤強度, さく孔データ $\left(1 / V^{*}\right)$ および実施支保パターンの掘進距離程 (TD) に伴う変化 （a）鈴鹿花崗岩を主体とする区間 （b）鮎川層群区間

表 3 坑壁観察に基づく地質概要と TBM データ (岩盤強度) の傾向

\begin{tabular}{|c|c|c|c|c|c|}
\hline TD3600 & TBM掘進方向 & & TD1926 & TD1345 & $T D(m)$ \\
\hline \multicolumn{2}{|l|}{ 鮎川層群 } & 黒滝断層 & \multicolumn{2}{|r|}{ 鈴鹿花崗岩 } & \multirow{3}{*}{ 地質区分 } \\
\hline 砂岩·礫岩! & & 断層 & \multirow{2}{*}{\multicolumn{2}{|c|}{ 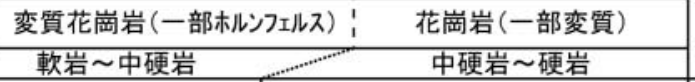 }} & \\
\hline \multicolumn{2}{|l|}{ 軟岩～中硬岩 } & 1 & & & \\
\hline 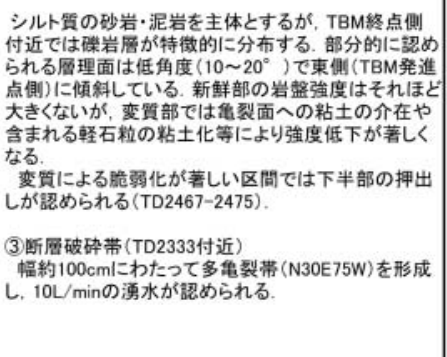 & 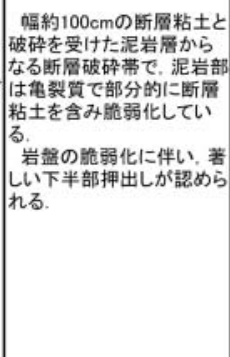 & 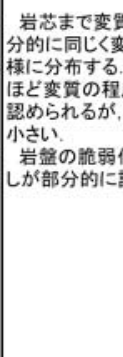 & 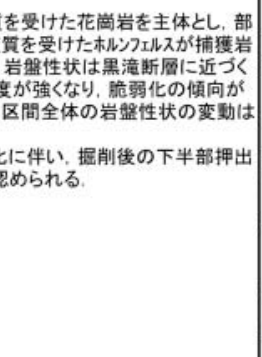 & 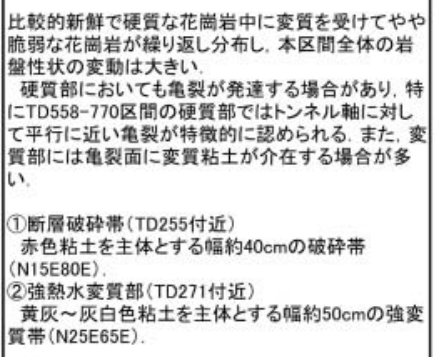 & 地質概要 \\
\hline 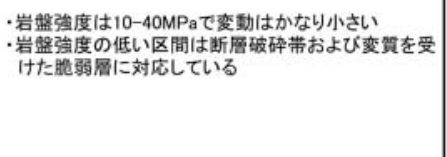 & $\begin{array}{l}\text { ·岩盤強度は10-20MPaてc } \\
\text { あり, 变峌は比较的小 } \\
\text { さい, }\end{array}$ & 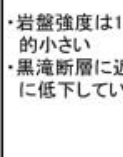 & 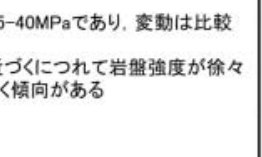 & 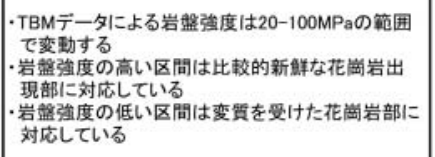 & $\begin{array}{l}\text { TBMデータ } \\
\text { (岩盤強度) }\end{array}$ \\
\hline
\end{tabular}

表 4 鈴鹿花崗岩および鮎川層群の支保パターンごとの岩盤強度

\begin{tabular}{|c|c|c|c|c|c|}
\hline \multirow{2}{*}{ 岩 種 } & \multirow{2}{*}{$\begin{array}{c}\text { 岩盤強度 } \\
(\mathrm{MPa})\end{array}$} & \multicolumn{4}{|c|}{ 支保パターン } \\
\hline & & B & C I & C II & D I \\
\hline \multirow{4}{*}{ 鈴鹿花崗岩 } & 平均値 & 55.8 & 46.6 & 28.7 & 23.6 \\
\hline & 標準偏羑 & 14.7 & 16.5 & 7.9 & 5.5 \\
\hline & 最大値 & 89.4 & 102.2 & 63.4 & 42.9 \\
\hline & 最小値 & 23.5 & 14.8 & 15.2 & 13.9 \\
\hline \multirow{4}{*}{ 鮎川層群 } & 平均値 & \multirow{4}{*}{ - } & 29.0 & 24.6 & 21.1 \\
\hline & 標準偏差 & & 5.2 & 4.9 & 6.1 \\
\hline & 最大値 & & 44.5 & 45.8 & 41.0 \\
\hline & 最小値 & & 12.7 & 13.9 & 8.6 \\
\hline
\end{tabular}


I パターンの曲線の傾きは C I および C II に比べて小さくなる 傾向が認められる。その要因の 1 つとして鮎川層群の D I パター ンでは岩盤強度に比較的大きな值 (30MPa 程度) を示すものが多 く含まれていることが挙げられる。これは, 比較的岩盤が硬質で あっても低角度傾斜 $\left(10 \sim 20^{\circ}\right)$ の層理面に沿って岩塊が崩落し易 いような区間に D I パターンを適用したことが原因と考えられ る。

\section{5. さく孔データと岩盤強度・地質性状の関係}

$\mathrm{TBM}$ の掘削距離程に対するさく孔データ $1 / V^{*}$ の分布状況を図 6 に示す。なお，ここでの $1 / V^{*}$ は $1 \mathrm{~m}$ 区間平均值を示している。全区 間を大局的に見てみると, $1 / V^{*}$ のばらつきや増加・減少といった変 動傾向は 4 ・ 1 節で述べた岩盤強度の傾向と概ね一致している。

ただし，TD500〜 TD750m 付近では岩盤強度の上昇区間におい て $1 / V^{*}$ の明瞭な上昇傾向が認められず, 両者の乘離が一部顕著に なっている。これら乘離区間の地質性状の特徴としては, 表 3 の 地質記事に記述したように硬質な花崗岩中にトンネル軸に平行に 近い方向に延びる亀裂密集部がさく孔探查孔周辺に分布している ことが挙げられる。このような局所的な地質性状の影響をさく孔 データがより強く受け, 岩盤強度と $1 / V^{*}$ の乘離が生じたものと考 えられる。

上述のような局所的な地質性状の変化が少ないと考えられる区 間から，表 5 に示すように岩種・性状別に代表的な区間を 4 区間 （区間(1)～(4) ) 抽出し，各区間における $1 / V^{*}$ と岩盤強度，地質性 状の詳細比較を実施した。

\section{$5 \cdot 1$ 区間(1) $($ TD850m 1,320m)}

表 5 区間(1)-(4)の岩盤性状

\begin{tabular}{|c|c|c|c|c|c|}
\hline & & \multicolumn{2}{|c|}{ 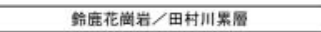 } & \multicolumn{2}{|c|}{ 的川層群 } \\
\hline \multicolumn{2}{|c|}{ 区間粪号 } & (1) & (2) & (3) & (4) \\
\hline \multirow{2}{*}{\multicolumn{2}{|c|}{$\begin{array}{l}\text { 区間 TD } \\
\text { 者保分名-ン }\end{array}$}} & TD $850-1.320 \mathrm{~m}$ & TD $1.650-1.920 \mathrm{~m}$ & TD 2,.650-2,900m & TD 2.920-3.120m \\
\hline & & B-CII & DI & $\mathrm{CI}$ & $C$ II $-D I$ \\
\hline 岩 & iit & 花崰岩 & 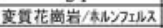 & 㢷岩/シルト筫祀岩 & シルト岩/シルト㙺㱠岩 \\
\hline \multirow{3}{*}{ 岩繁性状 } & 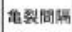 & $20-50 \mathrm{~cm}$ & $5-50 \mathrm{~cm}$ & $20-50 \mathrm{~cm}$ & $20-50 \mathrm{~cm}$ \\
\hline & 㔊目状態 & 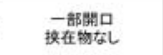 & $\begin{array}{l}\text { 盟口足 } \\
\text { 坫土挟む }\end{array}$ & 一邜開口 & 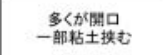 \\
\hline & 風化麦等 & 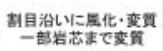 & 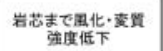 & 䃬ね新祭 & 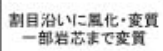 \\
\hline
\end{tabular}
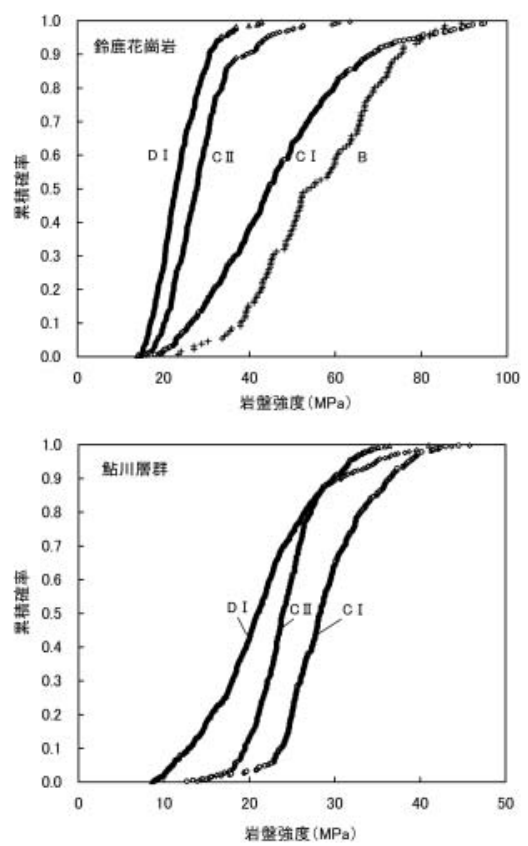

図 7 鈴鹿花崗岩および鮎川層群の各支保パターンにおけ る岩盤強度の累積確率分布
この区間は岩芯まで変質の影響を受けておらず，比較的硬質な 花崗岩を主体とするが, 亀裂の発達や亀裂に沿った変質作用等に より岩盤強度（性状）の変動が大きくなっている。亀裂性状は一 般に $20 \sim 50 \mathrm{~cm}$ 間隔であり，一部開口するものの挟在物は含まれ ない。実施支保パターンは B 〜 C II（一部 D I ）である。

図 8 に示すように本区間の $1 / V^{*}$ は $0.7 \sim 3.0$ 程度の幅（標準偏 差:0.386) で変動が認められ, 概ね 1.0 を超えた領域 (平均值:1.26) に分布している。この結果は, 本トンネルにおける平均的な花崗岩 よりも概ね硬質な性状を示寸ことを示唆している。このような $1 / V^{*}$ の変動傾向は岩盤強度の傾向 $(20 \sim 70 \mathrm{MPa}$ の間で大きく変動 $)$ と も概水一致している。

\section{$5 \cdot 2$ 区間(2) (TD1,650m 1,920m)}

この区間は岩芯まで変質の影響を受けて強度が低下した花崗岩 (一部ホルンフェルス) を主体としており, 表 3 の変質花崗岩区間 に含まれる。亀裂性状は一般に $5 \sim 50 \mathrm{~cm}$ 間隔であり, 開口部に 変質粘土の挟在が認められる。区間(1)の岩盤に比べて軟質ではあ るが, 亀裂の影響による岩盤性状のばらつきは小さく比較的均質 な性状を呈する。実施支保パターンは D I である。

図 9 に示すように本区間における $1 / V^{*}$ の変動幅は $0.5 \sim 1.2$ 程 度 (標準偏差:0.235) と区間(1)の花崗岩に比べて小さい。また，1/ $V^{*}$ の多くは 1.0 を下回る領域 (平均值: 0.82 ) に分布しており, 本卜 ンネルにおける平均的な花崗岩よりも脆弱な性状を示している。 このような $1 / V^{*}$ の傾向は, 上述の地質性状や岩盤強度の変動幅 (25MPa) が区間1)の花崗岩よりも小さいという結果とも一致す る。

\section{$5 \cdot 3$ 区間(3) (TD2,650m 2,900m)}

この区間の地質は概ね新鮮な鮎川層群の砂岩およびシルト質泥 岩であり, 花崗岩に比べて軟質である。亀裂性状は一般に 20 〜 $50 \mathrm{~cm}$ 間隔で一部開口部が認められるものの, 亀裂の影響による岩 盤性状のばらつきは小さく比較的均質な性状を呈する。実施支保 パターンは C I である。

図 10 に示すように本区間における $1 / V^{*}$ の変動幅は $1.0 \sim 1.3$ 程 度 (標準偏差:0.130) を示し, 変動幅は区間(2)の変質花崗岩よりも 更に小さくなる傾向が認められる。また， $1 / V^{*}$ の多くは 1.0 を上 回る領域 (平均值: 1.08) に分布しており, 本トンネルにおける平

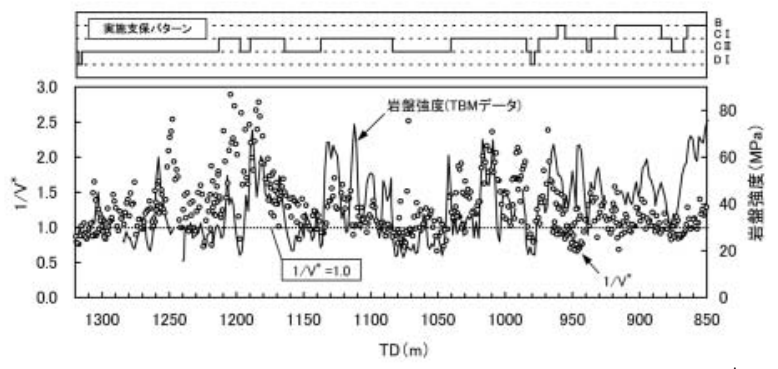

図 8 区間(1) ( 鈴鹿花崗岩 : B/C II パターン主体) における $1 / V^{*}$ と岩盤強度の比較

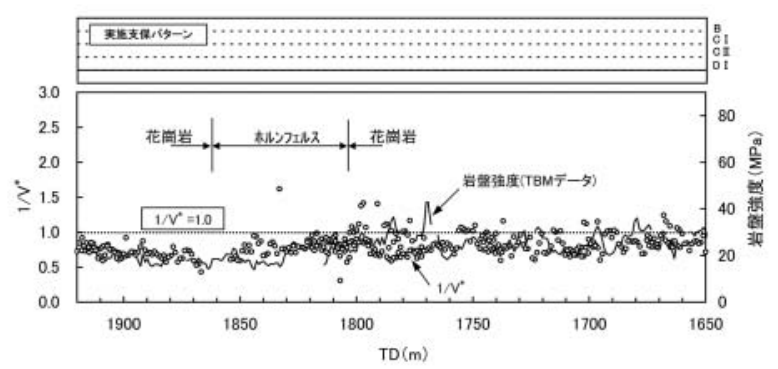

図 9 区間(2) (一部ホルンフェルスを含む鈴鹿花崗岩 : D I パ ターン)に打ける $1 / V^{*}$ と岩盤強度の比較 


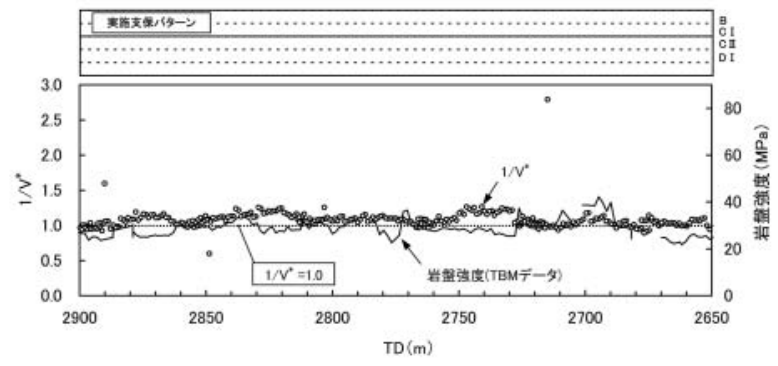

図 10 区間(3)(鮎川層群: C I パターン)における $1 / V^{*}$ と岩盤強度の比較

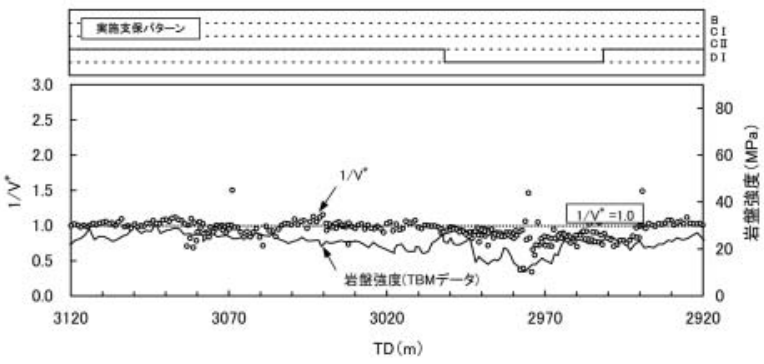

図 11 区間(4) (鮎川層群 : C II / D I パターン)における $1 / V^{*}$ と岩盤強度の比較

均的な鮎川層群よりもやや硬質な性状を示している。この傾向は, 上述の地質性状や岩盤強度の傾向とも概ね一致している。

\section{$5 \cdot 4$ 区間(4) (TD2,920m 3,120m)}

この区間は部分的に風化・変質を受けた鮎川層群のシルト岩お よびシルト質砂岩からなる。また, TD2,980m 付近には幅約 $1.0 \mathrm{~m}$ の断層破砕帯が認められ，その前後の区間は破砕帯の影響による 脆弱化が認められる。亀裂は区間(3)の鮎川層群と概ね同様の性状 を呈するが，上述の脆弱化区間では亀裂の開口や変質粘土の挟在 が一部認められる。実施支保パターンは脆弱化区間が D I , その 他の区間は C II となっている。

図 11 に示寸ように, $1 / V^{*}$ は C II 区間において 1.0 付近でほぼ一 定 (平均值: 0.97, 標準偏差:0.104) となっているのに対し, D I 区 間では $0.4 \sim 0.8$ 程度までの低下 (平均值: 0.85 , 標準偏差: 0.139 ) が認められる。岩盤強度においても C II 区間は $20 \sim 30 \mathrm{MPa}$ の間 で安定し，D I 区間では $10 \sim 15 \mathrm{MPa}$ にまで低下しており，1/V* と同様の傾向が認められる。

\section{6. 断層破砕帯におけるさく孔データ}

前章では, 数百 $\mathrm{m}$ 程度の区間におけるさく孔データと岩盤強 度・地質性状の関係について述べた。このような岩盤の平均的な 性状の把握以外に, さく孔探査の重要な目的の一つとして, 断層 破砕帯や大量湧水等の突発的な地質性状の悪化を事前に察知寸る ことが挙げられる。本トンネルにおいても複数の断層破砕帯が出 現しており，その中から 3 事例の探查結果について以下にその詳 細を述べる。なお，断層の出現想定を詳細に行うため, 以下の検 討では $1 \mathrm{~m}$ 区間平均データではなく 1 秒間隔 $(2.5 \mathrm{~cm}$ 前後 $)$ の詳細 さく孔データを用いた。

\section{$6 \cdot 1$ 鈴鹿花崗岩中の小断層}

本断層は TD $255 \mathrm{~m}$ 付近に出現し, 高角度傾斜でトンネル軸に高 角度で交差する走向を持つ小断層 $(\mathrm{N} 15 \mathrm{E} 80 \mathrm{E})$ で，幅約 $0.4 \mathrm{~m}$ の赤 色粘土を主体とする。断層周辺は全体的に熱水変質を受けており 脆弱化が進んでいる。また，断層部およびその周辺には少量の湧 水が認められ，部分的に粘土が流出している。

さく孔探査は TD248.1m 地点のトンネル天端部から前方に向け て約 $9^{\circ}$ 上向きに実施された。探查によって得られた断層周辺のさ

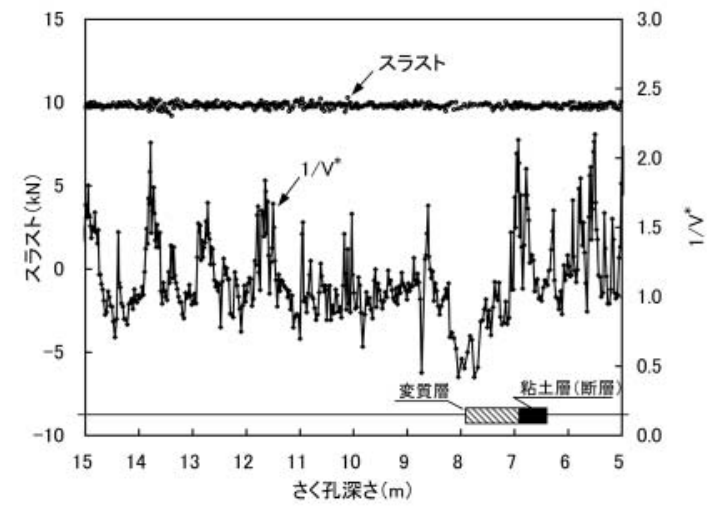

図 $121 / V^{*}$ の変動による鈴鹿花崗岩中の小断層の探査事例 図中の粘土層 (断層) および変質層は探査孔における出現位 置を示す

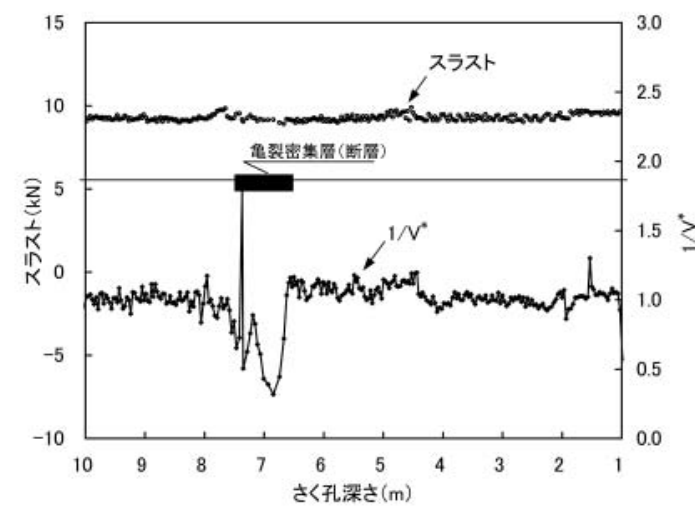

図 $131 / V^{*}$ の変動による鮎川層群中の小断層の探査事例 図中の亀裂密集層(断層) は探查孔における出現位置を示寸

く孔深さに対する $1 / V^{*}$ の変動およびさく岩機のスラスト力を図12 に示す。また, 図中には探査後の掘削によって坑壁に出現した対 象断層の探査孔における想定位置を示しており, 以降に示す出現 位置も探査孔への想定位置を示している。図中の区間における 1 / $V^{*}$ は概ね $0.8 \sim 2.0$ の範囲で変動しているが, さく孔深さ $7.6 \sim 8.2 \mathrm{~m}$ の約 $0.6 \mathrm{~m}$ 区間において $0.4 \sim 0.7$ 程度までの低下している。この 低下区間は約 $1.0 \mathrm{~m}$ の誤差があるもの, さく孔深さ $6.6 \sim 7.0 \mathrm{~m}$ 区 間に想定される断層部に対応しているものと考えられる。

\section{$6 \cdot 2$ 鮎川層群中の小断層}

本断層は TD2,333m 付近に出現し, TBM 掘進方向に約 $75^{\circ}$ の傾 斜角を持ち約 $55^{\circ}$ でトンネル掘進方向と交差するような走向を持 つ小断層で, 幅約 $1.0 \mathrm{~m}$ の亀裂密集帯を主体としている。断層およ びその周辺部では熱水変質による粘土の挟在は認められないが, 断層部の亀裂からは掘削時において約 $10 l / \min の$ 湧水が認められ た。

ここでのさく孔探査は, TD2,326.5m 地点のトンネル天端部から 前方に向けて約 $13^{\circ}$ 上向きに実施された。図 13 に示した探査区間 における $1 / V^{*}$ は概ね 1.0 程度で一定であるが，さく孔深さ $6.5 \sim$ $7.5 \mathrm{~m}$ の約 $1.0 \mathrm{~m}$ 区間において $0.3 \sim 0.8$ にまで低下している。この 低下区間は図に示した断層部想定位置にほぼ一致している。

\section{$6 \cdot 3$ 鈴鹿花崗岩と鮎川断層の境界断層（黒滝断層）}

黒滝断層は鈴鹿花崗岩と鮎川層群を境する断層であり, その出 現区間は TD 1,922〜1,938m の約 $16 \mathrm{~m}$ 区間にも及んでいる。黒滝 断層の主体をなすのは TD $1,926 \mathrm{~m}$ 付近に出現する幅約 $1.0 \mathrm{~m}$ の断層 粘土部であり，その前後の断層部は破砕を受けた鈴鹿花崗岩およ び鮎川層群からなる。断層区間には湧水は認められないが，脆弱 


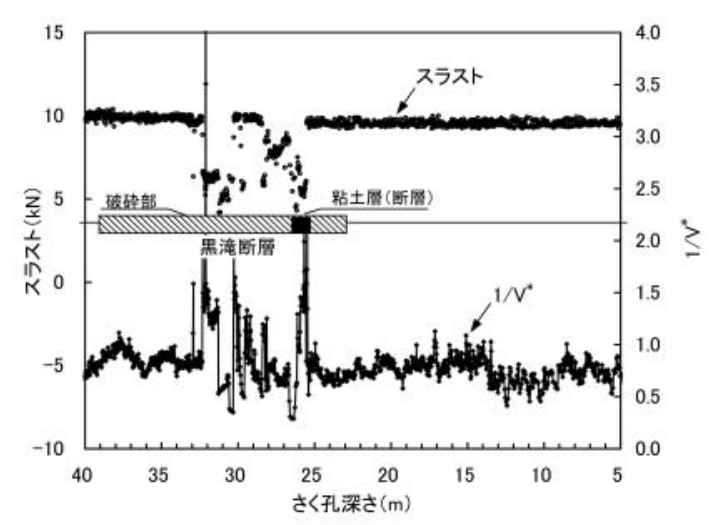

図 $141 / V^{*}$ の変動による鈴鹿花崗岩と鮎川層群を境する黒滝断層 の探査事例

図中の黒滝断層は探査孔における出現位置を示す

化によりトンネル下半部の著しい押出しが発生した。

断層近傍のさく孔探査はTD1,898.7m地点のトンネル天端部から 前方に向けて約 14 上向きに実施された。図 14 の探查区間におけ る $1 / V^{*}$ は概ね $0.5 \sim 1.0$ 程度の幅で変動しているが, さく孔深さ 約 $25.5 \sim$ 約 $32.5 \mathrm{~m}$ の約 $8.0 \mathrm{~m}$ 区間において概ね $0.3 \sim 2.0$ の範囲の 著しい変動が認められる。また, この区間ではこれまでに述べた 断層区間と異なり，さく岩機のスラストが設定值の $10 \mathrm{kN}$ を保持 することができず, 約 $5 \mathrm{kN}$ にまで低下する区間が一部見られた。 これは, ビット先端の岩盤がスラストを保持できないほど脆弱化 が激しいことを表している。図 14 に示すように, さく岩機のスラ ストの変動区間と黒滝断層の出現区間は概ね一致しており, 断層 部の脆弱化・不均質化がスラストの変動を招き, $1 / V^{*}$ の大きな変 動もそれに強く影響を受けたためと考えられる。

以上，3 つの事例に関して述べたが，それ以外にもさく孔デー タやスラストから事前予知が可能であった小断層 (幅 $40 \mathrm{~cm}$ 前後) もいくつか認められた。一方, 熱水変質粘土を含む幅数 $\mathrm{cm} \sim 20 \mathrm{~cm}$ 程度の脆弱層 ( シーム) については, 本手法による事前予知が困 難である場合もあったが，それらは施工に大きな影響を与えるも のではなかった。

\section{7. まとめと今後の課題}

本研究では, 鈴鹿トンネル TBM 導坑掘削時に実施された切羽 前方への長尺さく孔探查データを用いて, $1 / V^{*}$ を求めるとともに, $1 / V^{*}$ と岩盤特性の比較を行った。

$1 / V^{*}$ の優位性を再度確認するため, 岩盤性状が比較的均質で一 定している鮎川層群の C I パターン区間を例にとって, $1 / V^{*}$ とさ く孔深さ補正前のさく孔データ $(1 / V)$ を比較してみた（図 15)。な お, $V$ は, 図 3 に示した鮎川層群の初期深度における平均さく孔 速度 $(3.58 \mathrm{~cm} / \mathrm{s})$ で正規化した。 $1 / V^{*}$ は滑らかに変化し, TBM の 掘削抵抗から推定した岩盤強度との整合性がよかった。一方，1/ $V$ は，さく孔が切り替わる $2,850 \mathrm{~m}$ 付近， $2,900 \mathrm{~m}$ 付近， $2,940 \mathrm{~m}$ 付 近で急激に変化した。図に示した例では, 両者の差 ( 図中の $\Leftrightarrow$ ) は最大で $30 \%$ とかなり大きかった。

掘削岩盤の特性については, $1 / V^{*}$ の変動傾向により, 硬質岩盤 中の亀裂の発達による岩盤性状の変化や, 変質作用による軟質化 等を比較的正確に評価することができた。これは，さく孔探査が 支保パターンの事前想定やトンネル内空の変形挙動の推定にも応 用できる可能性を示している。ただし，さく孔探査による岩盤評 価範囲はトンネル断面に対して著しく小さいので, 掘削断面全体 に対する岩盤評価との乘離が一部の区間で認められた。このよう

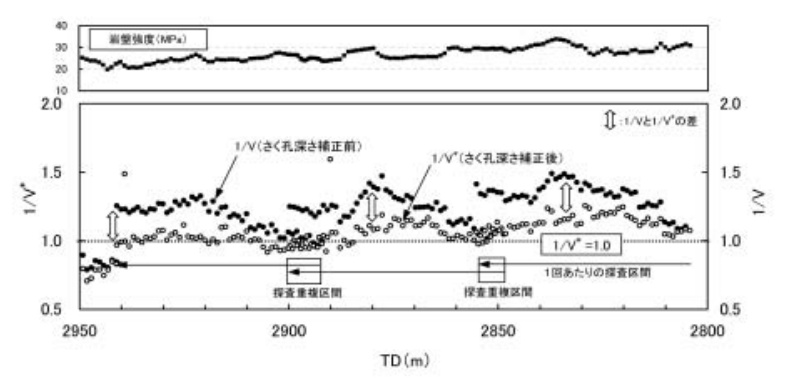

図15さく孔データのさく孔深さによる影響の補正前後の比較例 ( 鮎川層群)

な場合には, さく孔箇所を増やす必要があろう。

本トンネルに出現した幅 $0.4 \sim 1.0 \mathrm{~m}$ の粘土層や亀裂密集層を主 体とする小断層を, $1 / V^{*}$ の急激な低下によって事前予知すること ができた。また，幅 $10 \mathrm{~m}$ を超える比較的規模の大きい断層につい ては, さく岩機のスラストの低下を伴う $1 / V^{*}$ の変動によって把握 することができた。

$V^{*}$ を求めるために, $\overline{V\left(L_{0}\right)}$ を事前に求めておく必要がある。 $\overline{V\left(L_{0}\right)}$ は 岩盤を掘削した際の平均さく孔速度であるため, なるべく多くの 本数のデータを用いることが望ましい。これまでの経験的では, 比較的均質な岩盤であれば 5 本程度, 不均質な岩盤であれば 10 本 程度のデータが必要であった。また, 今回は鈴鹿花崗岩と鮎川層群 の 2 つに区分してそれぞれの $\overline{V\left(L_{0}\right)}$ を求めたが, 全区間の $\overline{V\left(L_{0}\right)}$ を 用いても， $1 / V^{*}$ の值は変化するが, 距離程に対する $1 / V^{*}$ の変動傾 向はほぼ同じであった。今回の計測結果に関する限り, 工区内の 地質区分にとらわれることなく, 掘削初期のデータから $\overline{V\left(L_{0}\right)}$ を 求めておけば, $1 / V^{*}$ の変動傾向が得られるといえる。

本研究で行った $1 / V^{*}$ による岩盤特性評価は, 現在のところ, 平 均的な岩盤特性を基準とした相対評価に留まっている。さく孔 データによる岩盤特性の定量的な評価を行うためには, $1 / V^{*}$ から 岩盤強度を推定する手法について検討を進めていく必要がある。 そのための課題として, さく孔距離による打撃数の変化や, スリー ブでの弾性波の減衰に関するデータの蓄積が挙げられる。今後, 岩盤特性の定量的な評価手法を開発するとともに, 切羽前方の地 下水やガスの賦存状況調査における $100 \mathrm{~m}$ を超える長尺さく孔調 查への本手法の適用を視野において研究を進める予定である。

本研究を進めるにあたり, 日本道路公団中部支社亀山工事事務所, 西松・三井住友・東洋建設共同企業体および古河機械金属（株）に ご協力いただいた。以上の方々に深く感謝の意を表する。

\section{References}

1) K. Fukui and S. Okubo: Tonneru-to-Chika, 29(1997), 123-131.

2) T. Tani and T. Aoki: Reports of Technical research Institute of Taisei Corporation, 31(1998), 165-168.

3) T. Yoshiki, Y. Naito, K. Nagase and Y. Ota: Tonneru-to-Chika, 35(2004), 21-27.

4) K. Fukui and S. Okubo: $9^{\text {th }}$ Int. Congress on Rock Mechanics, (1999), Vol.2, pp.12171220 .

5) H. Schunnesson: Int. J. Rock Mech. Sci., 35(1998), 711-725.

6) S. Hasidume, K. Ito, M. Arakawa and S. Minagawa: Proc. JSCE Annual Meeting, (1998), Part3, 246-247.

7) D. Ishimaru, S. Jinbo, K. Itakura, K. Sato, M. Nakata and H. Yamaji: Proc. MMIJ Spring Meeting, (2001), 258-259.

8) T. Kimura, M. Yamashita and S. Nishiyama: J. Soc. Mat., 52(2003), 494-499.

9) T. Yamamoto, S. Shirasagi, S. Yamamoto and K. Aoki: Proc. 31th Symposium of rock mechanics, (2001), 186-190.

10) B. Lundberg: Int. J. Rock Mech. Sci. \& Geomech. Abstr., 24(1987), 213-222.

11) K.Fukui, S.Okubo and M.Yamashita: Shigen-to-Sozai, 120(2004), 146-151.

12) K.Fukui, S.Okubo, K.Matsumoto, Y.Nawa, T.Sakai and I.Nishizawa: Shigen-to-Sozai, 116(2000), 831-838.

13) K. Ryoke, T. Aoki, Y. Tamura, K. Fukui, S. Okubo, K. Matsumoto and Y. Miyamoto: J.JSCE, 603(1998), PartIII-44, 89-100. 